\title{
Biological effect of Parsley and honey on side effects of Cisplatin induced nephrotoxicity in experimental male rats
}

Nawal A Tahoon

Department of Home Economic, Faculty of Specific Education, Benha University, Egypt

\section{ABSTRACT}

$T$

The research was carried out on 50 adult albino male rats (Sprague - Dawley strain) weighing $160 \pm 7 \mathrm{~g} .10$ rats served as control negative group and 40 rats were injected with Cisplatin $(7.5 \mathrm{mg} / \mathrm{kg} \mathrm{bwt}$, ip) to induce nephrotoxicity. Then, rats reclassified into positive control group and three treated rat groups which administered parsley juice with honey, parsley powder with honey, and parsley extract with honey. The treatment period was designed for eight weeks. The chemical composition revealed that dry parsley contain highest amount of protein, fat, ash, calcium, iron, zinc, potassium, sodium, magnesium, total polyphenols and total flavonoids than dry honey but dry honey contain highest amount of carbohydrate and moisture. The biological results revealed that, there was a significant increases in weight gain, food intake, feed efficiency ratio, protein efficiency ratio, serum total protein, globulin, albumin, and also kidney tissues superoxide dismutase (SOD), glutathione peroxidase (GPX) and glutathione-S- transferase (GST) antioxidant enzymes. There was a significant decrease in serum creatinine, urea and uric acid and albumin to globulin ratio and kidney tissues malondialdehyde (MDA) in all treated rat groups at $p<0.001$ compared with positive control group. Rat groups which administered Cisplatin showed a significant increase in creatinine, urea and uric acid and albumin to globulin ratio and kidney tissues malodialdehyde (MDA) and significant decrease in weight gain, food intake, food efficiency ratio, protein efficiency ratio ,serum total protein, globulin, abumin, And kidney tissues superoxide dismutase (SOD), glutathione peroxidase (GPX) and glutathione -S-transferase (GST) at $p<0.001$ compared with negative control group and all treated rat groups. Histopathological examination revealed that, kidney tissues of rat treated with administered parsley with honey showed apparent normal kidney and nonhistopathological changes. These biochemical changes were accompanied with histopathological. It can be concluded that the administration of Parsley juice, powder and extract with honey can lower the side effects of Cisplatin induced nephrotoxicity in human and reducing the risk factors for nephrotoxicity disease such as hyperemia, leakage of renal markers and healthy condition.

Key words: Parsley, honey, nephrotoxicity, Cisplatin \& rat 


\section{INTRODUCTION}

Several studies have also demonstrated that oxidative stress from cisplatin-mediated nephrotoxicity is involved in the development of this drug's renal tubule injury. The involvement of oxidative stress is further supported by the fact that free radical scavengers and antioxidants prevented. In addition to direct tubular toxicity in the form of apoptosis and necrosis, vascular factors and inflammation that has been implicated in the pathogenesis (Ekor et al 2010) Cisplatin is one of the most important chemotherapeutic of solid tumours; however, the clinical usefulness of cisplatin has been seriously restricted because of its nephrotoxic side effects (Kang and Lee 2004).

The parsley extract has a protective effect comparable to glibornuride against hepatotoxicity caused by diabetes due to its antioxidant property (Sacan et al 2006) .Parsley (Petroselinum crispum, Apiaceae) is one of the most used medicinal plants to treat arterial hypertension and renal diseases (Eddouks et al 2002 and Jouad et al 2001). The antioxidant and antibacterial activities of freeze-dried and irradiated parsley (Petroselinum crispum) and cilantro (Coriandrum sativum) leaves and stems were determined on methanol and water extracts. Several mechanisms of potential antioxidant activity of all extracts including determining relative free radical-scavenging and ferrous ion-chelating activities, as well as reducing power were examined. Assessment of the total antioxidant activity of all extracts was done using an ironinduced linoleic acid oxidation model system (Peter and David 2005). Medicinal plants and herbs play an important role in the prevention and treatment of kidney diseases.

Parsley (Petroselinum sativum, Family Apiaceae) is used as a culinary, garnishing and medicinal herb in the Mediterranean region of Southern Europe Parsley extract was reported to produce a diuretic effect and good antioxidant activity (Kreydiyyeh and Usta 2002). Parsley leaves are rich in Apigenin and its glucosidal 
Nawal A Tahoon

flavonoids that were found to possess anti-inflammatory especially for renal inflammation; antioxidant and anticancer activities (Dorman et al 2011 and Papay et al 2012). The aqueous extract of parsley reduced the number of calcium oxalate deposits and therefore parsley can be used for kidney and bladder stones (Saeidi et al 2012). The honey ameliorated renal oxidative stress and produced hypoglycemic effect in streptozotocin (STZ)-induced diabetic rats. The hypoglycemic effect of honey might partly be due to protection of pancreas against oxidative stress. Honey treatment reduced elevated MDA levels and increased SOD and CAT activities. Honey might be attributed to its antioxidative effect (Erejuwa $\boldsymbol{e t}$ al 2010).

The aim of the research work is to investigate the functional potency of parsley and honey as a nephroprotective food supplement on the side effects of Cisplatin induced renal damage in rats

\section{MATERIALS \& METHODS}

\section{Materials:}

50 adult albino male rats (Sprague - Dawley strain) weighing $160 \pm 7 \mathrm{~g}$ were obtained from National Research Center, Giza, Egypt. Rats were put in cages in an air conditioned unit and were fed on the standard diet which performed according to Reeves et al (1993). Cisplatin was purchased from Sigma St. Louis, MO, USA. The rat dose of cisplatin was $7.5 \mathrm{mg} / \mathrm{kg}$ body weight by interaperoitonal injection at first and $\mathbf{3 0}^{\text {th }}$ day according to Mansour et al., (2006). Biochemical kits were purchased from Alkan Co. for Chemicals and Biodignostics, Dokki, Egypt. Fresh Parsley and honey were purchased from Agricultural Research Centre, Giza Egypt.

\section{Methods}

\section{Preparation of Parsley}

Fresh Parsley plants were ground in a blender and filtering by using funnel and filter paper to obtain Parsley juice that given to rats at dose $8 \mathrm{ml} / \mathrm{kg}$ body weight by stomach tube. Other parts of fresh Parsley plants were cut into 
Nawal A Tahoon

small pieces, dried at $60^{\circ} \mathrm{C}$ in hot oven and crushed to a fine to obtain Parsley powder. Parsley powder was added as $15 \%$ of standard diet.

$5 \mathrm{~kg}$ of Parsley plant powder was mixed five times with $5 \mathrm{~L}$ methanol. The extract was filtered and the filtrate was evaporated to dryness with a rotatory vacuum evaporator at $50^{\circ} \mathrm{C}$ to give $150 \mathrm{~g}$. The Parsley extract was given to rats at dose $8 \mathrm{mg} / \mathrm{kg}$ bw and honey at dose $500 \mathrm{mg} / \mathrm{kg}$ bw Daily by stomach tube.

\section{Preparation of honey:}

Freeze dried honey powder using Freeze drying unit model EZ550Q FTS according to the methods of the (Ratti 2013)

\section{Chemical analyses of Parsley and honey:}

Moisture, protein, fat, ash, mineral elements such as Calcium, Iron, Zinc, Potassium, Sodium and Magnesium of Parsley and honey fine powder were determined separately according to the methods of the (A.O.A.C. 2000) While total carbohydrates were calculated by differences as following :
Carbohydrate $\%=100-$ (Moisture $\%+$ protein $\%+$ fat $\%+$ Ash\%).

Determination of the total phenolic compounds and total flavonoid of Parsley and honey: Total phenolic concentration was analyzed using the method described by singleton et al., (1965).Total flavonoid concentration was quantified using the spec- trophotometric method described by Jia et al (1999).

\section{Preparation of the basal diet:}

Basal diet was prepared according to Reeves et al (1993).

\section{Biological design:}

Rats were divided into 5 groups (each of 10 rats) as follows: Group one received normal saline (2 $\mathrm{ml} /$ day, i.p) acted as -ve control group. Group two received a dose of cisplatin, fed on standard diet and acted as +ve control group. Other three groups received cisplatin (7.5 $\mathrm{mg} / \mathrm{kg}$ bwt, i.p) and administered parsley juice with honey, parsley powder with honey and Parsley extract with honey all over period of the experiment, respectively. Daily food intake (FI) and weekly body weight gain (WG) were 
Nawal A Tahoon

recorded. Protein intake (PI), feed efficiency ratio (FER) and protein efficiency ratio (PER) were calculated according to Chapman et al (1950). After 60 days, rats were sacrificed and blood samples were collected for estimation of total protein, albumin, globulin, creatinine, urea and uric acid according to the following Bradford 1976, Doumas et al 1977, Henry 2001 Bonsens and Taussky 1984, Patton and Crouch 1977, Fossati et al 1980 ,respectively. The kidneys of each were immediately removed and homogenized in cold $\mathrm{KCl}$ solution $(1.5 \%)$ to give a $10 \%$ homogenate and used for measuring superoxide dismutase (SOD), glutathione peroxidase (GPX), glutathione -Stransferase (GST) and malodialdehyde (MDA) were estimated in the kidney tissues according to Misra and Fridovich (1972), Hissin and Hiff (1976), (Beutler et al 1963 and Habig et al 1974) and Draper and Hadley (1990) using kits purchased from Biodiagnostic, Egypt, respectively

\section{Histopathological examination:}

The fixed samples of kidney in $10 \%$ neutral buffered formalin was cleared in xylol and embeded in paraffin 4-5 $\mu \mathrm{m}$ thick section and stained with Hematoxylin and Eosin (H\&E) for subsequent histopathological examination Bancraft et al (1996).

\section{Statistical analysis}

Statistical analysis was done by using analysis of variance ANOVA followed by student's ttest according to Snedecor and Cochran, (1989)

\section{RESULTS}

The statistical data in table (1) denoted that the percentage values of gross chemical composition in dry parsley and honey were moisture $6.11 \pm 0.55$ and $11.77 \pm 1.11$, crude protein $5.01 \pm 0.33$ and $0.41 \pm 0.001$, crude fat $0.51 \pm 0.01$ and 000, ash $4.11 \pm 1.45$ and $0.45 \pm 0.051$, carbohydrate $84.26 \pm$ 10.49 and $90.37 \pm 14$ respectively. The content of some mineral, total Polyphenols and total Flavonoids in dry parsley and honey were calcium $250.33 \pm 11.46$ and $14.22 \pm 1.85$, 
iron7.11 \pm 1.35 and $0.67 \pm 0.01$, zinc $2.14 \pm 0.41$ and $0.09 \pm 0.002$, Potassium $235.11 \pm 12.35$ and $57.11 \pm 3.65$, Sodium $33.15 \pm$ 1.95 and $7.21 \pm 1.33$, Magnesium $42.13 \pm 2.45$ and $5.01 \pm 0.55$, Total Polyphenols $1456.77 \pm 110.85$ and $98.70 \pm 11.33$ and Total Flavonoids $189.31 \pm 19.97$ and $8.92 \pm 1.33$ respectively.

Table 2 showed that administration of cisplatin caused significant decreases in body weight gain, food intake, feed efficiency ratio, FER and protein efficiency ratio (PER) and that appeared in high significant decreases in $+v e$ control group at $\mathrm{p}<0.001$ compared to $-\mathrm{ve}$ control group. The administration of parsley juice, powder, and extract with honey and extract showed significant increase in body weight gain, food intake, feed efficiency ratio (FER) and protein efficiency ratio PER $(p<0.01)$ compared to + ve control but nonsignificant compared with -ve control group.

Table 3 showed that administration of cisplatin caused significant decreases in the levels of total protein and globulin $(\mathrm{p}<0.001)$ but albumin was within normal value compared to $-\mathrm{ve}$ control group. On the other hand, albumin/globulin ratio was significantly increased $(\mathrm{p}<0.001)$ compared to -ve control and all groups. The administration of parsley juice, powder and extract with honey showed normal values of total protein, albumin, globulin and albumin/globulin ratio.

Table 4 showed that administration of cisplatin caused significant increases in the serum levels of creatinine, urea and uric acid $(\mathrm{p}<0.001)$ compared to $-\mathrm{ve}$ control group. The administration of parsley juice, powder and extract with honey showed nonsignificant increase in creatinine, urea and uric acid compared to ve control group at $\mathrm{p}<0.05$ but significant decreased in compared with control +ve group at $\mathrm{p}<0.001$. The administration of Parsley juice, powder and extract with honey could lower the increase of creatinine and urea and uric acid was within normal value of -ve control Group at $\mathrm{p}<0.01$

Table 5 showed that administration of cisplatin caused significant decrease in kidney superoxide dismutase (SOD), glutathione peroxidase (GPX) and glutathione $-\mathrm{S}$ - transferase (GST) 
and significant increases in the level of malodialdehyde (MDA) at $\mathrm{p}<0.001$ compared to $-\mathrm{ve}$ control group. The administration of parsley juice, powder and extract with honey showed normal values of serum SOD, GPX, GST and MDA compared to -ve control group. The administration of Parsley juice, powder and extract with honey showed significant increase in kidney antioxidant enzymes SOD, GPX and GST and significant decreased in MDA compared to +ve control group at $\mathrm{p}<0.001$.

\section{Kidney Histopathological Results:}

Microscopically examination of kidney of negative control group revealed the normal histological structure of renal parenchyma (Pict. 1). Meanwhile, kidney of positive control group showed interstitial nephritis, cystic dilatation of renal tubules with eosinophilic protein cast (Pict. 2).However, kidney from Parsley juice with honey rat group revealed congestion of renal blood vessel and hypertrophy of glomerular tuft (Pict. 3). Kidney of Parsley powder with honey rat group revealed tubulo-interstitial nephritis (Pict. 4). No histopathological changes were noticed in kidney of Parsley extract with honey group (Pict. 5). Kidney of rat group's administration of Parsley juice, powder and extract with honey showed a slight congestion of renal blood vessel and recovering of normal glomerulus and renal tubules and improved injuries in renal tissues.

\section{DISCUSSION}

The present results of Cisplatin side effects either nutritional or biochemical were reported by several researchers. It has been demonstrated that Cisplatin induced nephrotoxicity evident by significant increases in serum urea, creatinine and uric acid associated with decreases in levels of kidney antioxidant enzymes activity .There were also significant increases in renal lipid peroxide malondialhyde (MDA) and marked tubular necrosis upon histopathological examination. These serum and tissue biochemical changes and histopathological alterations agreed with the previous reports (Tsuruya et al 2003 and 
Townsend et al 2009). Cisplatin is a widely used and highly effective cancer chemotherapeutic agent. It has also become apparent that inflammation provoked by injury to renal epithelial cells serves to amplify kidney injury and dysfunction in rats was found to be positively correlated with its outcome in humans. These results are consistent with the previous studies on Cisplatin administration decreased body weight and increased serum urea, creatinine and uric acid in comparison with the control rats. The activities of the antioxidant enzymes glutathione peroxidase and superoxide dismutase were also lowered but malondialdehyde (MDA) was higher in kidney tissue (Dogukan et al 2011). Oral administration parsley and honey with Cisplatin -nephrotoxic rats caused nephroprotective, diuretic and antioxidant effects as they reversed serum and kidney biochemical parameters and mitigated histopathological alterations in kidney induced by Cisplatin in rats. The improvement of nutritional status is related to Parsley is rich with an antioxidant arsenal that includes luteolin, flavonoid .That searches out and eradicates free radicals in the body that cause oxidative stress in cells. The Parsley is a powerhouse of nutrition, rich in tocopherol and vitamin A. It contains starch, vitamins $\mathrm{B}, \mathrm{C}, \beta$-carotene and zinc (Rashwan 2012). The parsley of the camp plants containing volatile oils such as alabiol, merstisinwabinin; plus it contains a high concentration of vitamins $(\mathrm{A}, \mathrm{B}, \mathrm{C})$, iron, calcium, potassium and sulfur Nutritional value, parsley also exhibits antioxidant and neutralizing properties (Vora et al 2012 ). Parsley is considered one of the basic foodstuffs as they contain folic acid, vitamin A or vitamin anti infection and vitamin $\mathrm{C}$ is important for preventing diseases and helps maintain the body's immune functions and parsley is a good aperitif, light Enhancer for digestion and the production of urine and menstrual flow increases (Khoshvakhti et al 2015). A polyherbal formulation containing parsley produced nephroprotective and diuretic effects in rats. The nephroprotective effect of parsley was attributed to the antioxidant activity due to its high content of 
flavonoids (Afzal et al 2004; AlGhamdi and AL-Amri 2016). The mechanism of diuretic action of parsley seems to be mediated through an inhibition of the $\mathrm{Na} / \mathrm{K}$ pump that would lead to a reduction in $\mathrm{Na}+$ and $\mathrm{K}+$ reabsorption leading thus to an osmotic water flow into the lumen, so causing dieresis.Concerning honey, it was reported that the honey also possesses natural antioxidants through many compounds like vitamin $\mathrm{C}$ and polyphenols like chrysin, pinobanksin, luteolin and pinocembrin that can decrease oxidative stress in humans(Kreydiyyeh and Usta 2002, Mahmood et al 2014.and Abbas and Abd-Elkhalik 2014 and Soliman et al 2015). The antioxidant effects of honey was attributed to its constituents like antioxidant trace elements and flavonoids compounds; therefore honey has been suggested to be able to decrease lipid peroxidation (Saravan,. and Mahitosh 2009). Honey is sweet, thick syrup made by honey bees from nectar of flowers, the flowers from which bees gather nectar largely determine the color, flavor, and aroma of honey( Sathyasurya and Aziz
2009). The antioxidant activity of honey is due to phenolic compounds and enzymes (glucose oxidase, catalase and peroxidase (Soria et al 2005; Vilma et al 2007; Cristine and Grael 2010). Also the content of L-ascorbic acid has a significant impact on total antioxidant activity of honey. It is basically a saturated water solution of sugar, which also includes a highly complex mixture of carbohydrates, enzymes, amino acids, organic acids, minerals, aromatic substances, pigments, wax, pollen (Dina et al 2005). The natural honey has protective effect against the damage in liver and kidney cells from oxidative stress induced by toxic level of lead in rats and found that coadministration of vitamins $\mathrm{C}$ and E significantly prevented the aminoglycosides-induced nephrotoxicity demonstrated by prevention of the elevation of urinary enzyme activities. Honey is essentially a concentrated aqueous solution of inverted sugar, but it also contains a very complex mixture of other saccharides, enzymes, amino and organic acids, polyphenols, carotenoid-like substances, Maillard reaction products, 
Nawal A Tahoon

vitamins, and minerals. (Halawa et al 2009). Honey is content flavonoids such as apigenin, pinocembrin, pinobanksin, kaempferol, quercetin, galangin, chrysin, and luteolin and phenolic acids such as caffeic, gallic, cinnamic, protocatechuic, pcoumaric, and chlorogenic acids (Lachman et al 2010). The honey serves as a source of natural antioxidants, which are effective in reducing the risk of heart disease, cancer, immunesystem decline, cataracts, different inflammatory processes(Gašić et al 2014) and so forth (NHB 2003 and Pérez et al 2006 ). Honey has been reported to be effective against enzymatic browning of fruits and vegetables. On account of its high nutritional value $(303 \mathrm{kcal} / 100 \mathrm{~g}$ honey) and fast absorption of its carbohydrates, honey is a food suitable for humans of every age. It is particularly recommended for children and sportsmen and by itself or associated with appropriate therapies; honey can help to improve the organism efficiency of the elderly and invalids (Chen et al 2000). The honey is classified as monofloral or polyfloral. monofloral honey is produced by one plant species containing predominantly its nectar with minor nectar contributions from other botanical origins. Polyfloral honey has several plant sources, none of which is predominant. In practical terms it can be considered as a blend of several monofloral honeys with significant nectar or honeydew contributions from different plants(Blasa et al 2006).Physicochemical, sensory, and health-protective characteristics of honey depend strongly on the plant species from which the nectar or the honeydew was collected, as well as climatic and environmental conditions, and processing methods(Gašić $\boldsymbol{e t}$ al 2014) .The nephroprotective potency of honey to its ability to stimulate inflammatory cytokine production from monocytes cells of the kidney. Protein in urine (proteinuria), especially at high levels,can indicate kidney disease or another serious condition.. The kidneys filter many substances, including waste products, from the blood. These waste products are then excreted in urine. Normally, during this filtering process, the kidneys retain components, including proteins, that the body needs (Oyefuga $\boldsymbol{e t}$ al 2016) The present results 
showed that the Parsley juice, powder and extract with honey the improvement of nutritional status, antioxidant activity and could decrease nephrotoxicity in rats.

\section{CONCLUSION}

Kidney dysfunction is a condition that its causes are too diverse and inclusive, particularly exposure to food oxidants and pollutants from drug. The prevention of side effect will be due to be consumption a natural common functional food. Therefore the study recommends that substituting sugars by honey and add parsley in diet might help to decreased kidney detoxification during treatment by Cisplatin

\section{REFERANCES}

Abbas SM and Abd-Elkhalik HA (2014):

"Nephroprotective,

Diuretic and Antioxidant Effects of Some Medicinal Herbs in GentamicinNephrotoxic Rats". J Intercult Ethnopharmacol; 3(1): 1-8.
Al-Ghamdi FAM and AL-Amri ASM (2016):

The protective role of parsley oil on kidney of the albino rat offspring's against toxity of Etoricoxib drug (Arcoxia) Life Science Journal;13(9):48-77.

A.O.A.C. (2000):

Official Methods of Analysis, Association Of Official Agriculture chemists, 17 Ed., vol.11, Virginia,U.S.A.

Afzal M; Khan NA; Ghufran A; Iqbal A and Inamuddin $M$ (2004):

Diuretic and nephroprotective effect of Jawarish Zarooni Sada,a polyherbal formulation.

Journal Ethnopharmacology, 91 : 219-223.

Bancraft J D; Stevens A and Turner DR (1996):

Theory and Practice of Histological Technique 4th Ed. New York, Churchill, Livingstone 
Beutler E; Duron $O$ and Kelly B M (1963):

"Improved method for the determination of blood glutathione." $J$ Lab Clin Med 61: 882-888.

Blasa M; Candiracci M; Accorsi A; Piacentini MP; Albertini MC and Piatti E (2006):

"Raw Millefiori honey is packed full of antioxidants," Food

Chemistry, vol. 97, no. 2, pp. 217-222.

Bonsens KE and Taussky DH (1984):

Determination of serum creatinine .J ChemInv, 27: 648-660.

\section{Bradford MM (1976):}

A rapid and sensitive method for the quantitation of microgram quantities of protein utilizing the principle of protein-dye binding analyte. Biochemistry 27, 248-254.

Chapman DG Gastilla $R$ and Campbell TA (1950):

Evaluation of protein in food.I. A. Method for the determination of protein efficiency ratio.Can. $J$. Biochem.Physio., I (37) 679-686.

Chen L; Mehta A; Berenbaum $M$; Zangerl AR and Engeseth NJ (2000):

"Honeys from different floral sources as inhibitors of enzymatic browning in fruit and vegetable homogenates," Journal of Agricultural and Food Chemistry, vol. 48, no. 10, pp. 4997-5000 .

Cristine FE and Grael S (2010): In vitro study of antioxidant and scavenger properties of phenolic compounds from lychnophora species. Maced J Med Sci.; 33:867870 .

Dina G, Natural Honey $Q$ and Wordfeeder A (2005): Science of food and Agriculture. 4:1-3.

Dogukan AM; Tuzcu CA;

Agca H; Gencoglu N; Sahin M; Onderci IH; Ozercan N; Ilhan $\mathbf{O}$; 
Kucuk and Sahin K (2011):

A tomato lycopene complex protects the kidney from cisplatin-induced injury via affecting oxidative stress as well as Bax, Bcl-2, and HSPs expression. Nutr Cancer.,63(3):427-34.

Dorman HJ; Lantto TA; Raasmaja $A$ and Hiltunen R (2011):

Antioxidant, pro-oxidant and cytotoxic properties of parsley. Food Function 2(6): 328-337.

Doumas BT; Watson WA and Biggs HG (1977):

Albumin standards and the measurement of serum albumin with bromocresol green. Clin. Chem. Acta., 31, 87-96.

Draper $H$ and Hadley $M$ (1990):

Malondialdehyde determination as index of lipid peroxidation. Methods Enzymol., 186: 421-431 .
Eddouks M; Maghrani M; Lemhadri A; Ouahidi M and Jouad H (2002):

Ethnopharmacological survey of medicinal plants used for the treatment of diabetes mellitus, hypertension and cardiac diseases in the south-east region of Morocco (Tafilalet). Journal of Ethnopharmacology 82, 97-103.

Ekor M; Emerole GO and Farombi EO (2010):

Phenolic extract of soybean (Glycine max) attenuates cisplatin-induced nephrotoxicity in rats. Food and Chemical Toxicology, 48: 1005-1012.

Pérez E1; Rodríguez-Malaver AJ and Vit P (2006):

Antioxidant capacity of renezvelan honey in wistar rat homogenates. $J \mathrm{Med}$ Food; 9(4): 510-516.

Erejuwa OO; Sulaiman SA; Wahab MS; Sirajudeen K N; Salleh MS and Gurtu S (2010): Antioxidant protection of Malaysian tualang honey in 
Biological effect of Parsley and honey on side effects of Cisplatin induced nephrotoxicity in experimental male rats

Nawal A Tahoon

pancreas of normal and streptozotocin-induced

diabetic rats Annales d'Endocrinologie, $\quad$ 71(4): 291-296.

Fossati P; Prencipe L and Berti G (1980):

Use of 3,5 dichloro-2hydroxybenzene sulfonic acid /4-amlnophenazon chromogenic system in direct enzymatic assay of uric acid in serum and urine. Clin. Chem., 26: $227-$ 231.

Gašić ; Kečkeš $S$ and Dabić D ( 2014):

"Phenolic profile and antioxidant activity of Serbian polyfloral honeys," Food Chemistry, vol. 145, pp. 599-607.

Habig WH; Pabst M J and Jakoby WB (1974):

"Glutathione S-transferases. The first enzymatic step in mercapturic acid formation." $J$ Biol Chem 249(22): 7130-7139.
Halawa H M; El-Nefiawy N E; Makhlouf N A and Mady A A (2009):

Evalution of honey protective effect on lead induced oxidative stress in rats. JASMR,; 2: 197-209.

Henry JB (2001):

Clinical Diagnosis and Management by Laboratory Methods, 20th ed. Philadelphia, PA: W.B. Saunders.

Hissin PL and Hiff R (1976):

A fluorometric method for determination of oxidized and reduced glutathione in tissues. Anal. Biochem, 74 (1): 214-226.

Jia Z; Mengcheng $T$ and Jianming W (1999):

The determination of flavonid contents in mulberry and their scavenging effect on superoxide radicals. Food chem. 64:555-559

Jouad H; Haloui M; Rhiouani $\mathrm{H}$; El-Hilaly J. and Eddouks M (2001): 
Biological effect of Parsley and honey on side effects of Cisplatin induced nephrotoxicity in experimental male rats

Nawal A Tahoon

Ethnobotanical survey of medicinal plants used for the treatment of diabetes, cardiac and renal diseases in the North centre region of Morocco (FezBoulemane). Journal of Ethnopharmacology 77, 175-182.

Kang DG and Lee S (2004):

Butein ameliorates renal concentrating ability in cisplatin-induced acute renal failure in rats. Biol. Pharm. Bull., 27: 366-370.

Khoshvakhti H; Kubra Yurt K; Zuhal Altunkaynak B; Aysın P; Turkmen; Ebru E; Işınsu A; Elfide G; Kıvrak M; Emin $O$ and Suleyman K (2015):

"Effects of melatonin on diclofenac sodium treated rat kidney:a stereological and histopathological study". Renal Failure; Volume 37, Issue 813

Kreydiyyeh SI and Usta J (2002):

Diuretic effect and mechanism of action of parsley. Journal of
Ethnopharmacology, 79(3): 353-357.

Lachman J; Orsák M; Hejtmánková A and Kovářová E (2010):

"Evaluation of antioxidant activity and total phenolics of selected Czech honeys," LWT-Food Science and Technology, vol. 43, no. 1, pp. 52-58.

Mahmood S; Hussain S and Malik F (2014):

Critique of medicinal conspicuousness of Parsley (Petroselinum crispum): A culinary herb of Mediterranean region. Pak. J. Pharm. Sci; 27(1):193202.

Mansour HH; Hafez HF and Fahmy NM (2006):

Silymarin modulates cisplatin-induced oxidative stress and hepatotoxicity in rats. J. Biochem. Mol. Biol., 39(6): 656-661.

Misra HP and Fridovich I (1972):

The role of superoxide anion in the antioxidant 
Biological effect of Parsley and honey on side effects of Cisplatin induced nephrotoxicity in experimental male rats

Nawal A Tahoon

epinephrine and a single assay of superoxide dismutase. $J$ Biol Chem.247:3170-5.
Enzymatic colorimetric method to determination urea in serum. Anal. Chem., 49: 464.

\section{National Honey Board (NHB)} (2003):

"Honey-Health and therapeutic qualities," 390 Lashley Street Longmont.

\section{Oyefuga OH; Alabi M A;} Idowu G; Fagbohun TR; Odufuwa KT; Iquot OS and Ashidi TF (2016):

Nephro-protective potency of natural honey: Report of preliminary study in white Wistar albino rats Biochemistry and Biotechnology Research Vol. 1(1), pp. 1-7.

Papay ZF; Kosa A; Boldizsar I;

Ruszkai A; Balogh E and Antal I (2012):

Pharmaceutical and formulation aspects of Petroselinum crispum extract, Acta Pharmaceutica Hungarica, 82(1): 3-14.

Patton CJ and Crouch S. (1977):
Peter YY and David DK (2005):

Studies on the dual antioxidant and antibacterial properties of parsley (Petroselinum crispum) and cilantro (Coriandrum sativum) extracts Food Chemistry, 97 (3): 505-515.

Rashwan NM (2012):

Biological study on the effect of arginine and parsley on renal toxicity in rats. World Journal of Medical Sciences,7 (4): 264-269.

Ratti C (2013):

Freeze drying for food powder production. In Handbook of Food Powders (B. Bhandari, N. Bansal, M. Zhang and P. Schuck, eds.) pp. 57-84, Woodhead

Publishing, Philadelphia 
Biological effect of Parsley and honey on side effects of Cisplatin induced nephrotoxicity in experimental male rats

Nawal A Tahoon

Reeves PG; Nielsen FH and Fahmy GG (1993):

AIN-93. Purified diets for laboratory rodents: Final report of the American Institute of Nutrition adhocwriling committee on the reformulation of the AIN-76 A Rodent diet. $J$. Nutrition, 123: 1939-151.

Sacan O.; Refiye O; Haci Y; Yasemin O; Aysen OY and Tugba $T$ (2006):

Effects of parsley (Petroselinum crispum) extract versus glibornuride on the liver of streptozotocin-induced diabetic urats Journal of Ethnopharmacology, 104 (1-2): 175-181.

Saeidi JM; Bozorgi H; Zendehdel A and Mehrzad J (2012):

Therapeutic effects of aqueous extracts of Petroselinum sativum on ethylene glycol-induced kidney calculi in rats. Urology Journal, 9(1): 361366.
Saravana KJ and Mahitosh M (2009):

Antiproliferative effect of honey and of polyphenols. Biomedicine and Biotechnology; 34: 1-10.

Sathyasurya DR and Aziz AlSafi I (2009):

Two varieties of honey that are available in Malaysia gave intermediate glycemic index values when tested among healthy individuals. Maced J Med Sci ,; 153(2). 145-148.

Snedecor, G.W. and Cochran, W.G. (1989):

Statistical Methods, seventh ed. The State University Press American, Iowa.

\section{Soliman HA; Eltablawy NA and Hamed (2015):}


Biological effect of Parsley and honey on side effects of Cisplatin induced nephrotoxicity in experimental male rats

Nawal A Tahoon

" The ameliorative effect of Petroselinum crispum (parsley) on some diabetes complications". Journal of Medicinal Plants Studies; 3(4): 92-100.

Soria AC (2005):

Estimation of the honeydew ratio in honey samples from their physicochemical data and from their volatile composition obtained by SPMP and GC-MS. Science and Agriculture of food; 85: 817-824

Townsend DM; Tew KD; King JB and Hanigan MH (2009):

Role of glutathione $S$ transferase $\mathrm{Pi}$ in cisplatininduced nephrotoxicity. Biomed. Pharmacother., 63, 79-85.

Tsuruya K; Ninomiya T; Tokumoto M; Hirakawa M; Matsutani K Aniguchi MT; Fukuda K; Kanai H; Kishihara K; Hirakata $\mathrm{H}$ and Iida $M$ ( 2003):

Direct involvement of the receptor-mediated apoptotic pathways in cisplatininduced renal tubular cell death. Kidney Int., 63, 7282.

Vilma B; Petras V and Violeta C (2007):

Radical scavenging activity of different floral origion honey and bee bread phenolic extracts. Elsevier,;30: 1-6.

Vora SR; Patil RB and Pillai MM (2012):

Oxidative Stress associated alterations in lysosomal enzymes and modulatory effect of Petroselinum crispum (Mill) Nyman Ex. A.W. Hill leaf extract on mouse brain. AmericanEurasian Journal of Scientific Research 7(2):6468. 
Biological effect of Parsley and honey on side effects of Cisplatin induced nephrotoxicity in experimental male rats

Table (1): Some grass chemical composition, polyphenols and flavonoids contents in dry parsley and honey

\begin{tabular}{|l|l|l|}
\hline Nutrient & Dry parsley & Dry honey \\
\hline Moisture \% & $6.11 \pm 0.55$ & $11.77 \pm 1.11$ \\
\hline Crude protein g \% & $5.01 \pm 0.33$ & $0.41 \pm 0.001$ \\
\hline Crude fats g \% & $0.51 \pm 0.01$ & 0000 \\
\hline Ash g \% & $4.11 \pm 1.45$ & $0.45 \pm 0.051$ \\
\hline Carbohydrates g\% & $84.26 \pm 10.49$ & $90.37 \pm 14.21$ \\
\hline Calcium mg/100g & $250.33 \pm 11.46$ & $14.22 \pm 1.85$ \\
\hline Iron mg/100g & $7.11 \pm 1.35$ & $0.67 \pm 0.01$ \\
\hline Zinc mg/100g & $2.14 \pm 0.41$ & $0.09 \pm 0.002$ \\
\hline Potassium mg/100g & $235.11 \pm 12.35$ & $57.11 \pm 3.65$ \\
\hline Sodium mg/100g & $33.15 \pm 1.95$ & $7.21 \pm 1.33$ \\
\hline Magnesium mg/100g & $42.13 \pm 2.45$ & $5.01 \pm 0.55$ \\
\hline $\begin{array}{l}\text { T Polyphenols mg/100g as mg gallic } \\
\text { acid }\end{array}$ & $1456.77 \pm 110.85$ & $98.70 \pm 11.33$ \\
\hline T Flavonoids mg/100g as mg rutin & $189.31 \pm 19.97$ & $8.92 \pm 1.33$ \\
\hline
\end{tabular}

Means \pm standard deviation of means of three determinations 
Biological effect of Parsley and honey on side effects of Cisplatin induced nephrotoxicity in experimental male rats

Table (2): Effect of parsley with honey on body weight gain, food intake, FER and PER of the experimental rat groups

\begin{tabular}{|c|c|c|c|c|c|}
\hline $\begin{array}{l}\text { Groups } \\
\text { Variables }\end{array}$ & $\begin{array}{l}\text { Control } \\
\text { (-ve) }\end{array}$ & $\begin{array}{l}\text { Control } \\
(+v e)\end{array}$ & $\begin{array}{l}\text { parsley } \\
\text { juice } \\
\text { with } \\
\text { honey } \\
\end{array}$ & $\begin{array}{l}\text { parsley } \\
\text { powder } \\
\text { with } \\
\text { honey }\end{array}$ & $\begin{array}{l}\text { parsley } \\
\text { extract } \\
\text { with } \\
\text { honey }\end{array}$ \\
\hline $\begin{array}{l}\text { Weight } \\
\text { gain (g) }\end{array}$ & $\begin{array}{l}94.33 \pm \\
9.41^{\mathrm{a}}\end{array}$ & $\begin{array}{l}46.77 \pm \\
5.80^{\mathrm{b}}\end{array}$ & $\begin{array}{l}92.11 \pm \\
8.99^{\mathrm{a}}\end{array}$ & $\begin{array}{l}90.41 \pm \\
8.22^{\mathrm{a}}\end{array}$ & $\begin{array}{l}88.91 \pm \\
7.33^{\mathrm{a}}\end{array}$ \\
\hline $\begin{array}{l}\text { Food } \\
\text { intake }(g / w)\end{array}$ & $\begin{array}{l}20.44 \pm \\
1.99^{\mathrm{a}}\end{array}$ & $\begin{array}{l}16.99 \pm \\
1.41 \mathrm{~b}\end{array}$ & $\begin{array}{l}19.22 \pm \\
1.61^{\mathrm{a}}\end{array}$ & $\begin{array}{l}19.41 \pm \\
1.51^{\mathrm{a}}\end{array}$ & $\begin{array}{l}\text { 19.35 } \pm \\
1.41^{\mathrm{a}}\end{array}$ \\
\hline FER & $\begin{array}{l}0.076 \pm \\
0.003^{\mathrm{a}}\end{array}$ & $\begin{array}{l}0.045 \pm \\
0.001^{\mathrm{b}}\end{array}$ & $\begin{array}{l}0.079 \pm \\
0.002^{\mathrm{a}}\end{array}$ & $\begin{array}{l}0.077 \pm \\
0.004^{\mathrm{a}}\end{array}$ & $\begin{array}{l}0.076 \pm \\
0.004^{\mathrm{a}}\end{array}$ \\
\hline PER & $\begin{array}{l}0.385 \pm \\
0.01 a\end{array}$ & $\begin{array}{l}0.229 \pm \\
0.010^{b}\end{array}$ & $\begin{array}{l}0.399 \pm \\
0.013^{\mathrm{a}}\end{array}$ & $\begin{array}{l}0.388 \pm \\
0.012^{\mathrm{a}}\end{array}$ & $\begin{array}{l}0.302 \pm \\
0.010^{\mathrm{a}}\end{array}$ \\
\hline
\end{tabular}

Each value is the mean $\pm S D$ Mean values in each row having different superscript $(\boldsymbol{a}, \boldsymbol{b}, \boldsymbol{c}$ $\& d)$ are significantly different at $P<0.05$

Table (3): Effect of parsley with honey on some renal parameters of control and renal damage rat groups at the end of study

\begin{tabular}{|c|c|c|c|c|c|}
\hline $\begin{array}{l}\text { Groups } \\
\text { Variables }\end{array}$ & $\begin{array}{l}\text { Control } \\
\text { (-ve) }\end{array}$ & $\begin{array}{l}\text { Control } \\
(+v e)\end{array}$ & $\begin{array}{l}\text { Parsley } \\
\text { juice with } \\
\text { honey }\end{array}$ & $\begin{array}{l}\text { parsley } \\
\text { powder } \\
\text { with honey }\end{array}$ & $\begin{array}{l}\text { parsley } \\
\text { extract } \\
\text { with honey }\end{array}$ \\
\hline $\begin{array}{l}\text { T. Protein } \\
\text { (g/dl) }\end{array}$ & $7.11 \pm 1.14^{\mathrm{a}}$ & $5 \pm 1.31^{b}$ & $6.51 \pm 1.35^{\mathrm{ab}}$ & $9.09 \pm 1.19^{\mathrm{ab}}$ & $6.44 \pm 1.64^{\mathrm{ab}}$ \\
\hline $\begin{array}{l}\text { Albumin } \\
\text { (g/dl) }\end{array}$ & $3.40 \pm 0.77^{\mathrm{a}}$ & $3.22 \pm 0.63^{\mathrm{a}}$ & $3.01 \pm 0.55^{\mathrm{a}}$ & $3.99 \pm 0.31^{\mathrm{ab}}$ & $3.02 \pm 0.60^{\mathrm{a}}$ \\
\hline $\begin{array}{l}\text { Globulin } \\
\text { (g/dl) }\end{array}$ & $3.71 \pm 0.88^{\mathrm{a}}$ & $1.89 \pm 0.26^{b}$ & $3.50 \pm 0.91^{\mathrm{a}}$ & $3.11 \pm 0.82^{\mathrm{a}}$ & $3.42 \pm 0.79^{a}$ \\
\hline $\begin{array}{l}\text { A/G ratio } \\
\%\end{array}$ & $0.91 \pm 0.19^{b}$ & $1.70 \pm 0.66^{\mathrm{a}}$ & $0.86 \pm 0.14^{b}$ & $0.96 \pm 0.12^{b}$ & $0.88 \pm 0.11^{b}$ \\
\hline
\end{tabular}

Each value is the mean $\pm S D$ Mean values in each row having different superscript (a, b, $\boldsymbol{c}$ $\& d)$ are significantly different at $P<0.05$ 
Biological effect of Parsley and honey on side effects of Cisplatin induced nephrotoxicity in experimental male rats

Table (4): Effect of parsley with honey on serum level of creatinine, urea and uric acid of the experimental rat groups at the end of study

\begin{tabular}{|c|c|c|c|c|c|}
\hline $\begin{array}{l}\text { Groups } \\
\text { Variables }\end{array}$ & $\begin{array}{l}\text { Control } \\
\text { (-ve) }\end{array}$ & $\begin{array}{l}\text { Control } \\
(+\mathrm{ve})\end{array}$ & $\begin{array}{l}\text { Parsley } \\
\text { juice with } \\
\text { honey }\end{array}$ & $\begin{array}{l}\text { parsley } \\
\text { powder } \\
\text { with honey }\end{array}$ & $\begin{array}{l}\text { parsley } \\
\text { extract } \\
\text { with honey }\end{array}$ \\
\hline $\begin{array}{l}\text { Creatinine } \\
(\mathrm{mg} / \mathrm{dl})\end{array}$ & $0.78 \pm 0.11 b^{c}$ & $1.98 \pm 0.65^{\mathrm{a}}$ & $0.85 \pm 0.14^{b}$ & $0.89 \pm 0.13^{b}$ & $0.88 \pm 0.12^{b}$ \\
\hline $\begin{array}{l}\text { Urea } \\
(\mu / \mathbf{m g})\end{array}$ & $35.11 \pm 5.96^{b c}$ & $87.33 \pm 9.11^{\mathrm{a}}$ & $40.33 \pm 6.71^{b}$ & $39.41 \pm 5.14^{b}$ & $38.77 \pm 5.33^{b}$ \\
\hline $\begin{array}{l}\text { Uric acid } \\
\text { (mg/dl) }\end{array}$ & $3.22 \pm 0.33^{b c}$ & $6.77 \pm 0.55^{\mathrm{a}}$ & $4.35 \pm 0.87^{b}$ & $4.12 \pm 0.88^{b}$ & $4.01 \pm 0.76^{b}$ \\
\hline
\end{tabular}

Each value is the mean $\pm S D$ Mean values in each row having different superscript $(\boldsymbol{a}, \boldsymbol{b}, \boldsymbol{c}$ $\&$ d) are significantly different at $P<0.05$

Table (5): Effect of Parsley with honey on kidney SOD, GPX, GSTand MDA of the experimental rat groups at the end of study

\begin{tabular}{|c|c|c|c|c|c|}
\hline $\begin{array}{l}\text { Groups } \\
\text { Variables }\end{array}$ & $\begin{array}{l}\text { Control } \\
\text { (-ve) }\end{array}$ & $\begin{array}{l}\text { Control } \\
(+\mathrm{ve})\end{array}$ & $\begin{array}{l}\text { Parsley } \\
\text { juice with } \\
\text { honey }\end{array}$ & $\begin{array}{l}\text { parsley } \\
\text { powder } \\
\text { with honey }\end{array}$ & $\begin{array}{l}\text { parsley } \\
\text { extract } \\
\text { with honey }\end{array}$ \\
\hline $\begin{array}{l}\text { SOD } \\
(\mu / \mathrm{mg})\end{array}$ & $93.51 \pm 9.11^{\mathrm{a}}$ & $36.17 \pm 5.41^{b}$ & $86.51 \pm 8.77^{\mathrm{a}}$ & $85.77 \pm 8.20^{a}$ & $88.33 \pm 7.99^{a}$ \\
\hline $\begin{array}{l}\text { GPX } \\
(\mu / \mathrm{mg})\end{array}$ & $83.77 \pm 8.45^{\mathrm{a}}$ & $31.41 \pm 4.80^{b}$ & $78.22 \pm 7.82^{a}$ & $77.31 \pm 6.77^{\mathrm{a}}$ & $79.36 \pm 7.01^{\mathrm{a}}$ \\
\hline $\begin{array}{l}\text { GST } \\
(\mu / \mathrm{mg})\end{array}$ & $5.41 \pm 1.26^{\mathrm{a}}$ & $2.30 \pm 0.37^{b}$ & $4.20 \pm 1.01^{\mathrm{a}}$ & $4.11 \pm 1.14^{\mathrm{a}}$ & $4.59 \pm 1.31^{\mathrm{a}}$ \\
\hline $\begin{array}{l}\text { MDA } \\
(\mu / m g \\
\text { protein })\end{array}$ & $6.22 \pm 1.49^{b}$ & $12.55 \pm 2.11^{\mathrm{a}}$ & $6.96 \pm 1.60^{b}$ & $7.81 \pm 1.55^{b}$ & $7.41 \pm 1.49^{b}$ \\
\hline
\end{tabular}

Each value is the mean $\pm S D$ Mean values in each row having different superscript $(a, b, c$ $\& d)$ are significantly different at $P<0.05$ 
Biological effect of Parsley and honey on side effects of Cisplatin induced nephrotoxicity in experimental male rats

Nawal A Tahoon

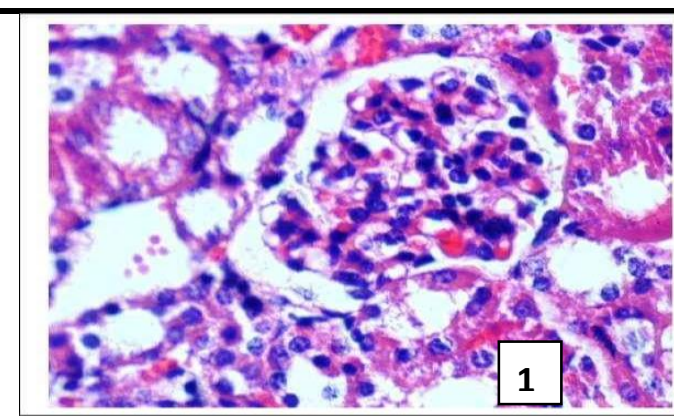

Section from renal tissues of control negative normal histological structure of renal parenchyma

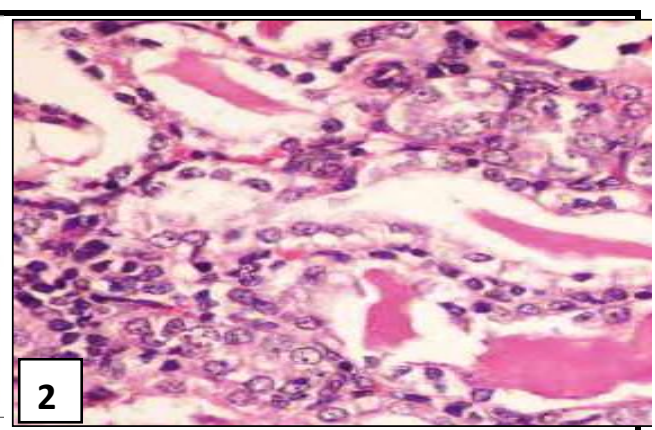

Section from renal tissues of control positive interstitial nephritis, cystic dilatation of renal tubules with eosinophilic protein cast

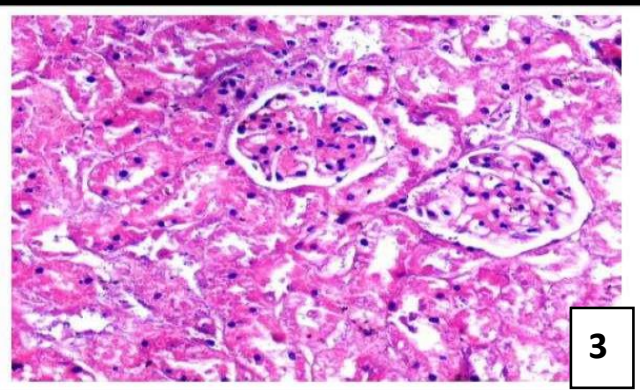

Section from renal tissues of Parsley juice with honey group revealed congestion of renal blood vessel and hypertrophy of glomerular tuft

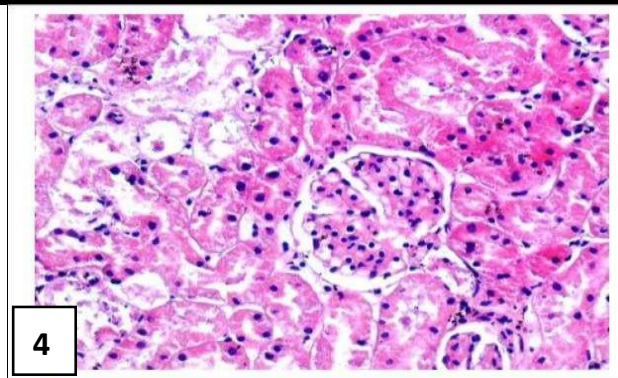

Section from renal tissues of Parsley powder with honey group revealed tubulointerstitial nephritis

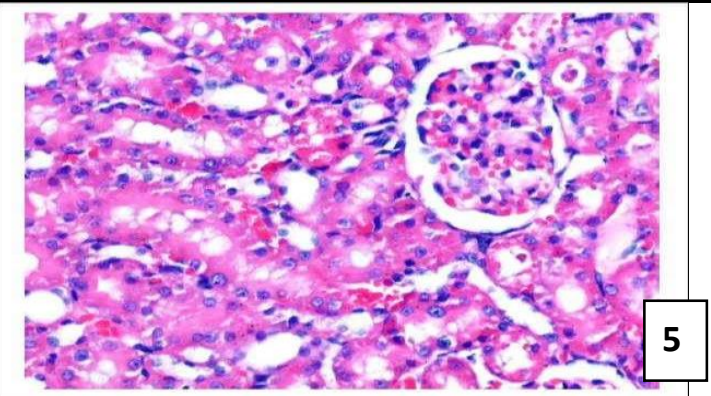

Section from renal tissues of Parsley extract with honey group No histopathological changes were noticed in kidney tissues 


\section{التأثثر البيولوجي للبقدونس والعسل على الآثار الجانبية للسيسبلاتين

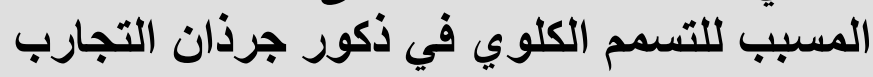 \\ نوال عباس طاحون \\ قسم الاقتصاد المنزلي - كلية التربية النوعية - جامعة بنها - مصر عال طر

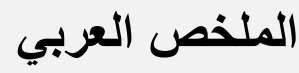

أجريت الدراسة على •0 من ذكور الجرذان البيضاء البالغة من فصيلة اسبر/جي - داولي والتي بتراوح

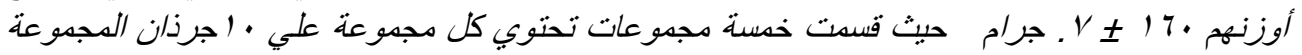

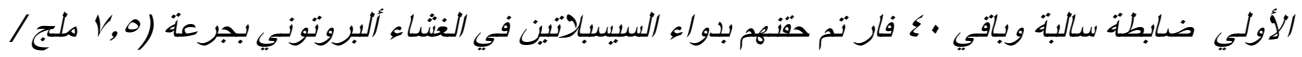

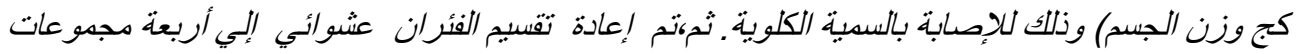

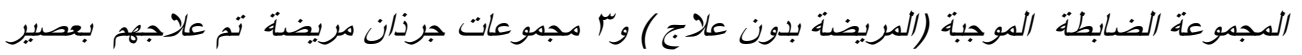

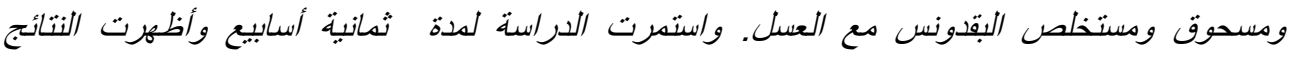

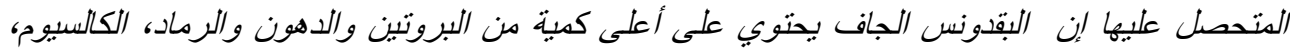

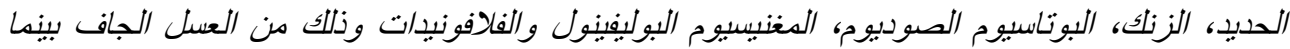

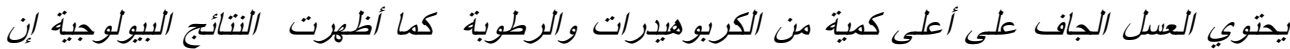

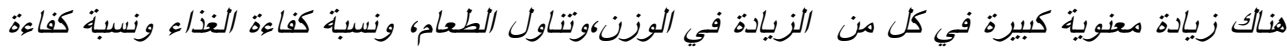

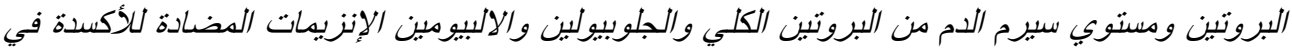

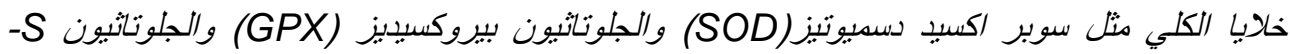

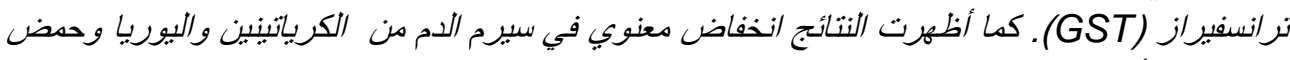

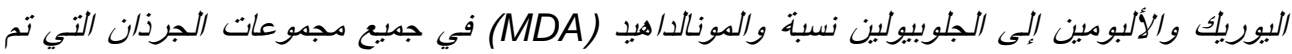

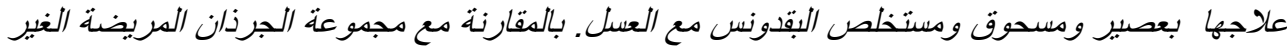

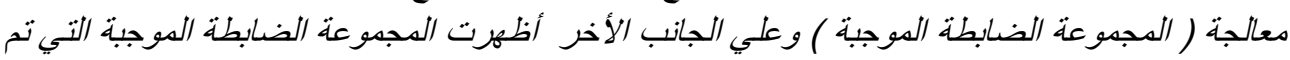

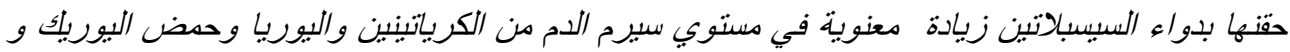

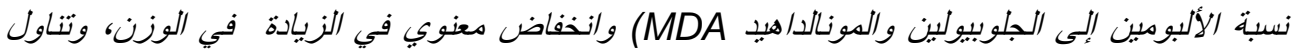

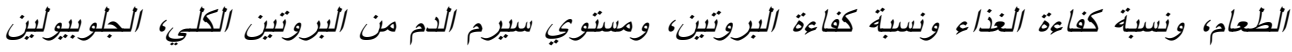

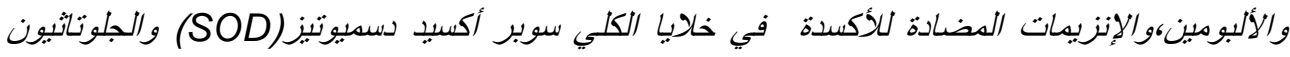

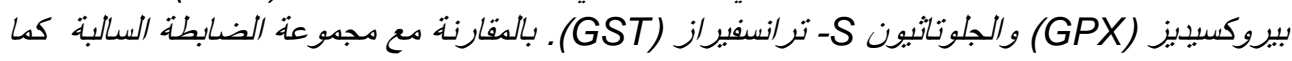

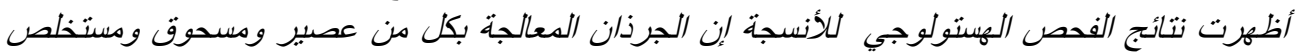

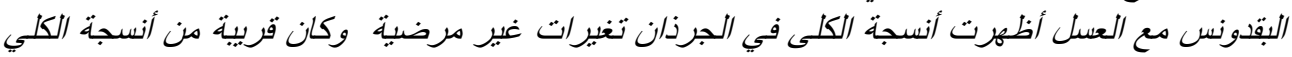

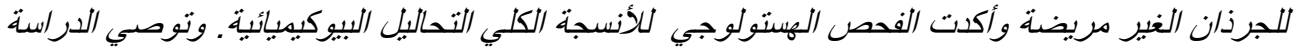

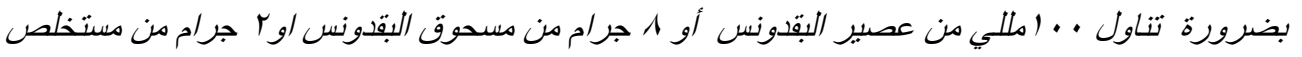

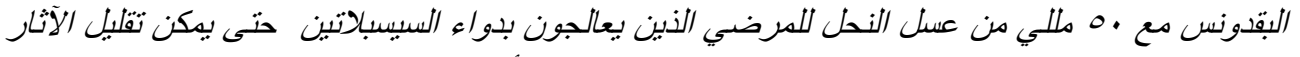

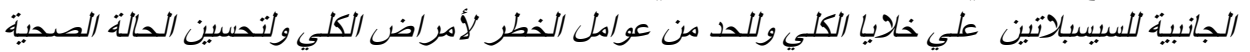

$$
\text { الكلمات المفتاحية البقدونس - العسل- السبيسباتين -التسمم الكلوي- جرذان التجارب }
$$

